Forum

\title{
Aboriginal Precedent for Active Management of Sagebrush-Perennial Grass Communities in the Great Basin
}

\author{
J. Kent McAdoo, ${ }^{1}$ Brad W. Schultz, ${ }^{2}$ and Sherman R. Swanson ${ }^{3}$
}

Authors are ${ }^{1}$ Associate Professor/Natural Resources Specialist, University of Nevada Cooperative Extension, Elko, NV 89801, USA; ${ }^{2}$ Professor/Extension Educator, University of Nevada Cooperative Extension, Winnemucca, NV 89445, USA; and ${ }^{3}$ Associate Professor, College of Agriculture, Biology, and Natural Resources, University of Nevada, Reno, NV 89512, USA.

\begin{abstract}
Until recently, most contemporary ecologists have ignored or diminished anecdotal historical accounts and anthropologists' reports about aboriginal fire in the Great Basin. Literature review shows that Indians practiced regular use of fire for many purposes, including the obvious reasons of increasing the availability of desired plants, maintaining habitats for animals used as food, and driving game during hunts. Historical accounts of prehistoric anthropogenic firing, inferences from fire-scar data, and data regarding annual production capability of representative sagebrush (Artemisia spp.)-perennial grass ecological sites indicate that prehistoric conditions were neither fuel- nor ignition-limited. According to many sources, this "active management" by Indians was widespread, significant, and more common than lightning-caused fires, resulting in mosaic vegetation patterns that subsequently moderated the behavior of "natural fires." This interaction between Indian-burning and lightning fires may have strongly influenced the pre-Euro-American settlement vegetation of the Great Basin. At the very least, the landscape was a patchwork of areas altered by aboriginal people and areas shaped primarily by bio-physical processes. Based on this prehistoric precedent, current historically unprecedented conditions (fuel load and exotic weed invasion threats), and predicted climate change, contemporary active management of sagebrush-perennial grass communities is paramount. Restoration measures should be scientifically based and tailored to achieve ecological resilience and functionality in specific sites. Prescribed fire is not always ecologically appropriate or judicious, especially in Wyoming big sagebrush (A. tridentata spp. wyomingensis) communities, so managers should consider using other alternatives where an intentional low severity distubance is deemed necessary. Properly planned active management would disrupt fuel continuity for lighthning fires, ensure ecological process and successional integrity, and benefit multiple uses on a landscape scale.
\end{abstract}

Key Words: aboriginal fire, Artemisia, disturbance, historic range of variation (HRV), rangeland restoration, resilience

\section{INTRODUCTION}

Aboriginal manipulation of North American vegetation, primarily by burning, has been widely reported in the anthropological literature (e.g., Lewis 1985; Boyd 1986; Turner 1991; Pyne 1993, 1995; Gottesfeld 1994; Stewart 2002), but these findings have been largely ignored by ecologists (Kay 1995; Anderson 2002). In today's “back to nature" mindset, it may be more politically convenient to assume that because humans are often the cause of environmental degradation, direct involvement/manipulation by humans is undesirable. However, removing human influence from a landscape, often advocated for conservation purposes, can actually erode the qualities that were intended to be preserved (Botkin 1990; McCann 1999b). By ignoring the active management by historic occupants of the Great Basin, we may be dismissing critical precedent that has implication for our current situation of frequent fire and dominance of exotic annual grass in lower

This paper was funded in part by the USDA-ARS Area-Wide Ecologically Based Invasive Plant Management program.

Correspondence: J. Kent McAdoo, University of Nevada Cooperative Extension, 701 Walnut St, Elko, NV 89801, USA. Email: mcadook@unce.unr.edu

Manuscript received 30 December 2011; manuscript accepted 15 February 2013.

(c) 2013 The Society for Range Management elevations (Davies et al. 2011b), lack of periodic fire and subsequent conifer encroachment at higher elevations (Miller and Rose 1999), and loss of sagebrush-perennial grass community resilience after disturbance and resistance to exotic weed invasion (Davies et al. 2011b).

According to Williams (2000), marginalization of traditional knowledge arose partly out of ignorance and prejudice, but also because of the fragmentary nature of the evidence. Qualitative, anecdotal accounts of aboriginal burning found in notes, journals, and tribal oral tradition are not readily accepted by western scientists who, by training, focus on replicated, controlled experimentation and quantitative data. Furthermore, much traditional knowledge has been lost to time and forced assimilation (Kimmerer and Lake 2001; Stewart 2002). But there is little doubt that Native Americans fully understood the benefits they could receive by firing their environments (Anderson 2005).

If aboriginal burning was common before Euro-American settlement, there should be some historical and ecological evidence of such disturbance regimes. Contemporary ecological science suggests that fire disturbance within intact sagebrushperennial grass communities results in herbaceous dominance for several years after the disturbance. "These communities evolved with periodic fires shifting dominance from shrubs to herbaceous species" (Davies et al. 2008, p. 1076). Seefeldt et al. 
(2007) reported that the herbaceous component of intact mountain big sagebrush (A.t. spp. vaseyana) communities can return to prefire conditions within three $3 \mathrm{yr}$ after fall prescribed burning. According to Gruell and Swanson (2012), vegetation descriptions recorded by early explorers/travelers in the Great Basin were highly variable, largely a function of the ecological sites encountered and time since last disturbance. The landscapes also had much variability in topography, geomorphology, and soils across relatively short distances. For example, G. Stewart (1941), summarizing historical records based on technical reports from government surveys, historical documents/records, and diaries, indicated a predominance of perennial grass in northwest Utah; the area described consists primarily of elevated valleys, foothills, and benchlands. Similarly, government reports and accounts of explorers and early settlers indicated that pre-Euro-American settlement vegetation in the Cache Valley of Idaho and Utah had a major grass component (Hull and Hull 1974). In comparison, Vale's (1975) description of the early contact Intermountain West landscape as "visually dominated by shrubs" (p. 32) is based almost entirely on reports regarding explorer/settler travel routes through semiarid valleys, taken for relative ease of access. These areas were often dominated by basin big sagebrush (A.t. spp. tridentata), rabbitbrush (Chrysothamnus spp.), greasewood (Sarcobatus spp.), and saltbush (Atriplex spp.), which the early travelers referred to collectively as "sagebrush" (Young et al. 1979).

Gruell and Swanson (2012) cited many historical documents and newspaper articles documenting the abundance of grass that attracted ranchers to northern Nevada in the mid-1800s. One such account, in a March 16, 1870, editorial of the Elko Daily Free Press, stated: "In the summer season we have rich bunchgrass covering every hillside with a luxuriant growth..." Historic photographs in the shrubsteppe hills of this area show the dominance of native grasses (Gruell and Swanson 2012). The preponderance of perennial grass and forbs in at least some areas may be inferred by the relative abundance of pronghorn antelope (Antilocapra americana) and bighorn sheep (Ovis canadensis), grass- and open-habitat adapted wildlife species that were apparently more common than shrub-dependent species like mule deer (Odocoileus hemionus) in some areas of the Great Basin during both prehistoric and early historic times (Pippin 1979; Matheny et al. 1997; Sands et al. 2000; Gruell and Swanson 2012). Although pronghorns are considered a sagebrush habitat obligate, their affinity for relatively open habitat with short sagebrush and abundant herbaceous vegetation has been documented for the Great Basin (Yoakum 1974, 1978). Similarly, the formerly abundant white-tailed jackrabbits (Lepus towensendii) have an affinity for more grass-dominated habitats (Verts and Carraway 1998). Once the focus of repeated $110-\mathrm{km}$ (one-way) migratory hunts by aboriginals in Grass Valley, central Nevada (Steward 1938), white-tailed jackrabbits are gone from much of their range in this area (Gruell and Swanson 2012). In comparison, the sagebrush obligate sage-grouse (Centrocercus urophasianus) was, based on anecdotal accounts, locally abundant in some areas but uncommon in others (Ridgway 1877; Klebenow 2001; Gruell and Swanson 2012) during the early Great Basin settlement period by Euro-Americans.
Paige and Ritter (1999), summarizing ecological literature, historical accounts, and explorer reports, concluded that before Euro-American settlement, "spotty and occasional wildfire probably created a patchwork of young and old sagebrush (Artemisia spp.) stands across the landscape, interspersed with grassland openings, wet meadows, and other shrub communities" (p. 6). In drier regions of the Great Basin where the Wyoming subspecies of big sagebrush (A.t. spp. wyomingensis) dominates, the fire regime was different (as described below) than that in higher precipitation areas (typically upper elevations) where the mountain subspecies of big sagebrush is more common (Tisdale and Hironaka 1969; Miller and Eddleman 2001).

Miller and Eddleman (2001), summarizing ecological literature, concluded that Wyoming big sagebrush and low sagebrush $(A$. arbuscula) communities had less frequent disturbance events but slower recovery rates than the mountain big sagebrush communities, which had more frequent disturbance and faster recovery rates. This created a mosaic of several successional stages across the landscape. Miller and Eddleman (2001) also indicated that, because of the resulting limited and discontinuous fuels, fires often left unburned islands, especially in Wyoming big sagebrush communities. Plant composition therefore varied across a spectrum of seral stages from dominant stands of sagebrush to grasslands, with much of the sagebrush steppe ecosystem comprised of open shrub stands with a strong component of perennial grasses and forbs. Fires in the mountainous areas created mosaics, with differences in slope and aspect, broken topography, and variation in fuel loads resulting in unburned patches after a fire. Weather conditions also affected historic patterns of vegetation composition on sagebrush landscapes (Miller and Eddleman 2001). Wigand et al. (1995) posited that during the Little Ice Age (LIA), the wettest and coolest period of the Holocene, herbaceous production was higher than in contemporary times. This increased grass cover likely supported higher fire frequencies (Miller et al. 2005). Certainly fire and weather were not the only sagebrush reduction agents. Sagebrushdefoliating insects (e.g., aroga moth [Aroga websteri]) may have reduced shrub cover in some areas, presumably with a corresponding increase in herbaceous vegetation, more likely by thinning sagebrush than eliminating it (Evers et al. 2013). Impacts from drought, freezekill, disease, and small mammals could also have reduced sagebrush in some areas, resulting in a successional shift to an earlier seral stage (Evers et al. 2013).

Summarizing an extensive review of historical literature, Gruell and Swanson (2012) concluded that accounts of early explorers, immigrants, government exploration/survey parties, and ethnographer interviews with Native American elders collectively reflected differences in ecological site potential and fire frequency. According to these authors, sagebrush and saltdesert shrubs dominated in the lower semiarid valleys, while riparian zones in these valleys supported an abundance of grasses, sedges, and small willows. Reflecting the occurrence of Indian burning and naturally occurring lightning fires, the upland communities were in early to mid-succession, supporting an abundance of bunchgrasses and open to moderate canopies of sagebrush. The growth form and distribution of woody plants reflected relatively frequent fire disturbances. In the mountains, the presence of small willows (Salix spp.) and 


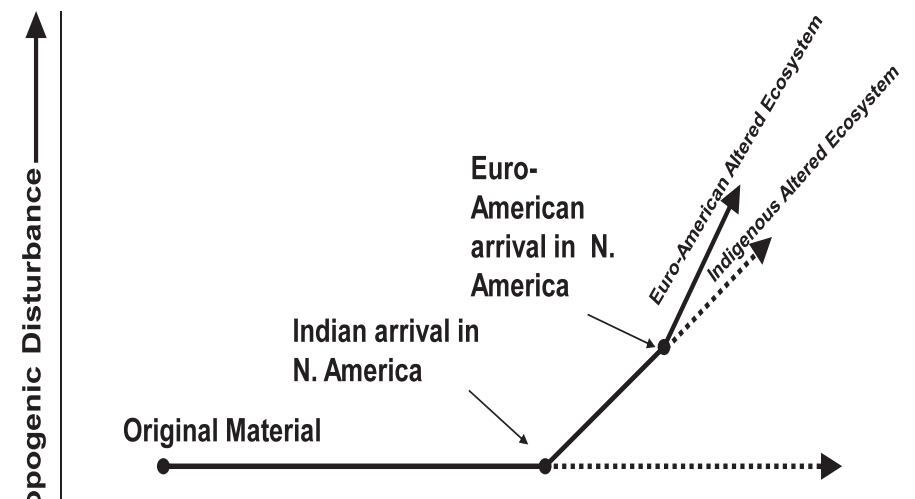

Original ecosystem (in the absence of indigenous disturbance)

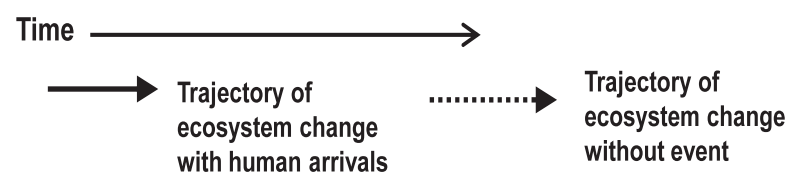

Figure 1. Ecosystems and anthropogenic influences (adapted from Anderson 2002).

aspens (Populus tremuloides spp.) suggests that these fireadapted plants were in early succession. Fire-sensitive mountain mahogany (Cercocarpus spp.) was restricted to ridges and upper slopes where fuel discontinuity limited fire spread. An abundance of bunchgrass reflected frequent fire disturbance. Gruell and Swanson (2012) concluded that semiarid valleys (dominated by basin and/or Wyoming big sagebrush) apparently burned infrequently because of sparse grass and discontinuous shrub cover.

The historic differences among sagebrush-perennial grass communities across landscapes and through time, as impacted by disturbances before Euro-American settlement, may have important implications for contemporary vegetation management. The objectives of this article are to: 1) document, through literature review, practices of aboriginal vegetation management in the Great Basin, 2) vet these findings by comparing to inferences from fire-scar studies and information on the annual production capability of representative intact sagebrush-perennial grass ecological sites, and 3) discuss the implications of any such precedent for contemporary vegetation management.

\section{EVIDENCE FOR INDIAN-MANAGED ECOSYSTEMS}

\section{North America in General}

The most powerful tool that aboriginal people had for landscape manipulation was fire, which was used to modify the environment for survival (Kimmerer and Lake 2001; Keeley 2002). Not surprisingly, the use of fire by indigenous people has affected in some way every ecosystem in North America (Pyne 1982; Gruell 1985; McCann 1999a; Williams 2000; Kimmerer and Lake 2001). According to Anderson (2002), humans are an ecological force within an ecosystem, influencing its trajectory in ways that are often highly culture-specific (Fig. 1). Anderson (2002) also maintained that the purposeful use of fire enabled
Native Americans to systematically alter their environment over long periods of time and at scales varying from individual shrubs to whole bioregions.

Aboriginals repeatedly burned vegetation to modify plant and animal communities for human benefit and to increase productivity (Pyne 1995). Williams (2000) listed 11 general reasons for aboriginal use of fire (Table 1). Lewis (1973) identified 70 specific reasons why California native peoples burned the vegetation. According to Anderson (2002, p. 63), "Fire not only warmed hearths and kept predators at bay; it increased forage for wildlife, curtailed insects that plagued food crops, and promoted long, straight shoots for basketry.” Based on 145 western US fire accounts from 1776 to 1900 as reported in 44 journals and other historical documents describing the activities of fur trappers, explorers, government surveyors, naturalists, emigrants, and military expeditions, ecologist George Gruell (1985) concluded that 41\% of fires observed were ignited by Indians, located primarily in upper elevations, and often spread unchecked.

\section{Great Basin}

Anthropologist Julian H. Steward, based on his extensive investigations on cultural elements of Great Basin Indian tribes (Steward 1933, 1938, 1941, 1943), concluded that aboriginals in the area "changed the natural landscape by repeated firings, probably intentional as well as accidental ...” (Steward 1949, p. 278). Steward described fire as being used frequently and widely by the Indians, maintaining that fire was often the primary factor determining the "natural vegetation" of the Great Basin and Plateau. A recently published book, Forgotten Fires-Native Americans and the Transient Wilderness, includes a thorough review of aboriginal fire across North America, including a 26-page chapter about the Great Basin and Plateau area (Stewart 2002). The manuscript was written in the 1950s by anthropologist Omer Stuart, but not published until half a century later after being discovered by Henry $\mathrm{T}$. Lewis (University of Alberta) and M. Kat Anderson (University of California, Davis). According to Anderson (2002), Stewart was prescient, ahead of his time in recognizing that indigenous fire management practices had significant consequences on vegetation and wildlife. Through an extensive literature review, Stewart (2002, p. 233) concluded that, "The statements of burning by Indians ... are sufficient to support the conclusion that fire was used by Indians of the Great Basin and Plateau regularly and for many purposes." This conclusion was based on the results of tribal interviews by anthropologists (Table 2) and corroborating visual observations from early explorations between 1776 and 1878 within the sagebrush region of Utah, Nevada, Idaho, Oregon, and interior Washington (Table 3). Native Americans also had reason to minimize fire or use it selectively in some areas/seasons to avoid damaging important resources, such as productive nut-producing pinyon pine (Pinus edulis) groves, fuel for cooking fires, hiding cover for stalking game, etc.

Rexford Daubenmire was among the earliest American ecologists to recognize the importance of fire's influence on plant life in this region. Under the subheading "The Fire Climax," he concluded based on a 3-yr ecological study of sagebrush vegetation in southeastern Washington and Idaho: 
Table 1. Reasons for aboriginal burning (adapted from Williams 2000).

\begin{tabular}{|c|c|}
\hline Activity & Description \\
\hline Hunting & To divert big game species into small, unburned areas for easier hunting, provide feeding areas, and drive game. \\
\hline Crop management & To improve seed harvest, increase berry production, clear ground for planting, etc. \\
\hline Range management & To improve game grazing/browsing potential. \\
\hline Fireproofing areas & To protect certain medicinal plants, clear areas around villages, and reduce shrub and tree encroachment. \\
\hline Insect gathering & "Fire surrounds" to collect and roast crickets, grasshoppers, etc. \\
\hline Pest management & To reduce flies, ticks, mosquitoes, rodents, etc. \\
\hline Warfare and signaling & To deprive enemy of hiding places; for offensive reasons as well or to escape enemy; for signaling, large fires were used. \\
\hline Economic extortion & To implement "scorched earth" policy, depriving enemies of food sources, etc. \\
\hline Clearing areas for travel & To clear trails and/or improve visibility in overgrown areas. \\
\hline Felling trees & To kill so that wood could be used later. \\
\hline Clearing riparian areas & To clear brush for new grasses and shrub/tree sprouts. \\
\hline
\end{tabular}

"Locally, the practice of burning the vegetation, which was started by the aborigines and is continued today, appears to have played a great part in eliminating Artemisia from the Artemisietum, especially in the northern and western parts of the zone" (Daubenmire 1942, p. 62).

Griffin (2002), integrating successional fire ecology and anthropological studies of historic subsistence patterns, resource use, and environmental manipulation, echoed many of Stewart's and Steward's observations. He noted that “... frequent to intermediate disturbance rates in both shrub communities and pinyon pine woodlands would have supported the subsistence patterns that (Julian) Steward and other anthropologists have described" (Griffin 2002, p. 88). More specifically, he indicated that Ute, Paiute, Shoshone, and Washoe hunter-foragers of the region "... likely benefited from periodic fires in the primary habitats they utilized” (p. 78), and that "the only environmental manipulation capable of widespread ecological change that was available to the aboriginal inhabitants was intentional burning” (p. 84). Griffin (2002) concluded that because of subsistence patterns, intentional burning could have affected vast acreages of this region.

Obviously, aboriginals in the Great Basin set fires for the same reasons that hunter-gatherers worldwide do: to cultivate and/or increase the availability of desirable plants, maintain habitats for prey animals, and drive game species during hunts. Other authors have also noted the importance of prehistoric and historic anthropogenic fires in and near the Great Basin. Gruell (1985) identified early historical descriptions of 43 fires in the Great Basin (between 1776 and 1900), 26 of which were reported as having been set intentionally. Based on her knowledge of aboriginal subsistence practices and vegetation ecology, Fowler (1986) speculated that the anthropogenic fires witnessed by Dominguez and Escalante in 1776 in Utah Valley, Utah, may have been a result of the frequent practice of fall burning by Indians rather than a defensive tactic. Burning during the fall was done apparently for the purpose of increasing spring yields (Fowler 1986), maintaining forage for game, and preparing areas for sowing of wild seeds (Steward 1941). According to Shinn (1980), aboriginal desert economies benefitted from late summer/fall burns because this was the annual period for gathering, preparing, and storing food supplies for winter. For North America in general, the majority of intentional aboriginal fires were set in the spring or late in the fall when burning conditions were less severe (Kimmerer and Lake 2001). Modern ecologists have noted that many cool season grasses in the northern Great Basin are least detrimentally affected by autumn fires when these species are dormant (Bunting et al. 1987; Seefeldt et al. 2007; Davies et al. 2008).

Shinn (1980) and Harper (1986), integrating ecological literature, historical records, and anthropological studies, concluded that Indian burning of sagebrush-steppe communities of the inland Pacific Northwest and Great Basin was both widespread and significant. Similarly, Rhode (1999), reviewing anthropological and paleo-ecological studies, indicated that the prehistoric inhabitants of the Great Basin probably exerted significant environmental effects with fire at some times and in some areas.

\section{DO MODERN MEASURES OF PAST FIRE OCCURRENCE REFLECT ABORIGINAL FIRE USE?}

Scientific accounts in the literature for estimated fire recurrence in both the mountain and Wyoming big sagebrush communities

Table 2. Documentation of Indian use of fire from ethnographic histories across the Great Basin.

\begin{tabular}{|c|c|c|}
\hline Ethnographic study & Geographic location & Statement \\
\hline Steward $(1938,1941,1943)$ & E. Nevada, W. Utah, S. Idaho, and W. Wyoming & Fire used to hunt deer and antelope and harvest seed. \\
\hline Kelly (1932) & Surprise Valley, CA & $\begin{array}{l}\text { Only means of taking deer wholesale was by firing ... late summer, } \\
\text { usually mid-August. }\end{array}$ \\
\hline Steward (1933) & Owens Valley, CA & Fire drives for hunting and burning for better wild-food crops. \\
\hline Steward (1941) & Central Nevada & Indians continually burned over country. \\
\hline $\begin{array}{l}\text { Drucker (1941), Stewart (1942), } \\
\text { and Steward (1941) }\end{array}$ & N. Arizona, S. Utah, and S. Nevada & Fire used to drive antelope and rabbits and increase seed yield. \\
\hline
\end{tabular}


Table 3. Observations by early explorers regarding Indian use of fire in the sagebrush region (compiled from Thomas 1983; Stewart 2002; Gruell and Swanson 2012).

\begin{tabular}{|c|c|c|c|}
\hline Authority & Geographic location & Year & Statement \\
\hline Escalante & Utah Lake, UT & 1776 & Meadows and pasture recently burned ... [Indians] had put fires everywhere \\
\hline Bryant & Morgan Valley, UT & 25 July 1846 & Smoke column rising from mountains to the West \\
\hline Bryant & Salt Lake Valley, UT & 30 July 1846 & Fire raged on mountain all night \\
\hline Egan & UT Territory & $1846-1878$ & Rabbit hunting fire drives by Goshutes \\
\hline Ogden & $\begin{array}{l}\text { Independence Valley and Santa Rosa Mountains, } \\
\text { northeast NV }\end{array}$ & 1829 & [Indian] fires in all directions \\
\hline Leonard & Humboldt River, near Lovelock, NV & 1833 & Smoke rising from the grass in every direction \\
\hline Fremont & Humboldt River, NV & 1845 & Indians in fall set fire to grass \\
\hline Lienhard & Goshute Valley, northeast NV & 26 August 1846 & [Indian] fires on nearby hills and mountains \\
\hline Bryant & Halleck, NV & 8 August 1846 & $\begin{array}{l}\text { Fires ignited by Indians were visible in mountains and several places in } \\
\text { valley a few miles distant }\end{array}$ \\
\hline Kilgore & Goose Creek, northeast NV & 1850 & $\begin{array}{l}\text { Saw Indian set fires (note: same area where Ogden suspected Indian fires } \\
\text { had affected beaver habitat in 1826) }\end{array}$ \\
\hline Egan & Ruby Valley, NV & 1850s & Multiple fires set by Indians to drive jackrabbits \\
\hline Burton & $\begin{array}{l}\text { Toiyabe Mountains and Roberts Creek Mountains, } \\
\text { central NV }\end{array}$ & 1860 & $\begin{array}{l}\text { Sighted everywhere on the heights the fires of the natives; from the hills } \\
\text { rose the smoke of Indian fires }\end{array}$ \\
\hline Triplet & Lower Humboldt River, NV & 1862 & Indian signal fires on top of every mountain \\
\hline Bonneville & Boise, ID & 1833 & Indians set fire to grassy plains \\
\hline Furnham & Ft. Hall, ID & 1839 & Indians burned prairie, burning large sections of most productive part \\
\hline Cox & Interior, WA & 1831 & $\begin{array}{l}\text { Indians set fire to the long grass, the flames of which spread with great } \\
\text { rapidity to drive game }\end{array}$ \\
\hline Saint-Amant & Umatilla River, OR & 1854 & Indians set fires to entire prairies \\
\hline
\end{tabular}

are quite variable (Baker 2006). At the low end of the spectrum, mean fire return interval (MFRI) for mountain big sagebrush ranges from 6 to $60 \mathrm{yr}$, based on multiple sources in Table 4 as well as Heyerdahl et al. (2006) and Miller and Rose (1995). Most estimates of MFRI in Wyoming big sagebrush communities are not empirically based, but the product of opinion and circumstantial evidence, e.g., estimated time for sagebrush to re-establish (Miller et al. 2011). Based on macroscopic charcoal work in central Nevada, Mensing et al. (2006) recorded MFRI of up to a century for Wyoming big sagebrush communities in central Nevada, varying with climate and fuel-load. At the upper end of the spectrum, Baker (2006) determined that fire rotation for mountain big sagebrush is 70 to $200 \mathrm{yr}, 100$ to $240 \mathrm{yr}$ for Wyoming big sagebrush, and 325 to $450 \mathrm{yr}$ for low sagebrush. However, these calculations were based on 20th century data for ignition and fire spread within grazed landscapes with reduced fine fuels and altered species composition. Much of the difference between these extremes is explained by examining terminology definitions (from the Fire Effects Information Systems Glossary; US Forest Service 2011). MFRI (also called "mean fire free interval" or "mean fire interval") is the arithmetic average of all fire intervals determined in a designated area during a designated time period; the size of the area and the time period must be specified (units=years). On the other hand, fire rotation is the length of time necessary for an area, equal for the entire area of interest, to burn; area of interest must be clearly identified (units=years/area). Fire rotation is based on two adjustments: percent of the area unburned in a fire and adjacency to a forest.

The macroscopic charcoal analysis by Mensing et al. (2006) to reconstruct fire history in central Nevada showed that the fire regime was climate and fuel driven; sagebrush increased and fires were more abundant during periods of wetter climate, and vice-versa. By combining fire scar, fire rotation, charcoal, and vegetation recovery data, Baker (2011) estimated that sagebrush communities burned at multicentury levels. According to Romme et al. (2009, p. 217), “... the sagebrush community is very heterogeneous, and a single, broad characterization of historical fire rotations cannot adequately convey the complex historical role of fire in these ecosystems."

Estimating fire frequency is fraught with complications. Fule et al. (2006) maintained that the MFRI is more relevant than fire rotation. Fire rotation does not provide consideration of variability across space or time (Reed 2006). According to Miller et al. (2011), large fires dominate the fire rotation computation and are best calculated for an area that exceeds the largest fire expected in one rotation. Reed (2006) suggested that the fire rotation concept be abandoned because fire size is a totally random event and fire rotation does not reflect the burning potential at any point, whereas the true fire cycle is measured by the expected fire interval at a point. But even the more frequent fire occurrences estimated by using MFRI may not accurately reflect how often areas once burned (Kay 2007). In much of the Great Basin, and particularly among Wyoming big sagebrush, black sagebrush ( $A$. nova), and low sagebrush communities, there are few if any old trees to record fire events (Gruell 1996). Therefore, MFRI estimates in the most arid or low-producing sagebrush sites are broad estimates based on little if any data from tree rings. Another problem is that not all fires scar all trees, and some trees are not susceptible to scarring (Young and Evans 1981). 
Table 4. Fire history of areas in or adjacent to sagebrush communities as determined from tree ring analysis (studies 1 to 8 ) or inferences (study 9 ) based on vegetation parameters (described in footnotes).

\begin{tabular}{|c|c|c|c|}
\hline Study No./Author(s) & Location & Sagebrush community & Mean fire return interval in yr (range) \\
\hline 1/Gruell (1999) & $\begin{array}{l}\text { Hart Mountain, OR; Great Basin National Park, } \\
\text { NV; Walker River, NV }\end{array}$ & Mountain & $8-29(3-32)$ \\
\hline 2/Miller and Rose (1999) & Paisley, OR & Mountain & $12-15(3-28)$ \\
\hline 3/Young and Evans (1981) & Lassen County, CA & Low & $31(10-95)$ \\
\hline 4/Miller et al. (2001) & Southeast OR & Mountain & $6-18(3-32)$ \\
\hline 5/Arno and Gruell (1983) & Southwest MT (Dillon area) & Mountain & $21-60(5-97)$ \\
\hline 6/Burkhardt and Tisdale (1976) & Owyhee County, ID & Mountain & $14-29(10-60)$ \\
\hline 7/Kitchen (2010) & $\begin{array}{l}\text { White Pine County, NV; Millard and Beaver } \\
\text { Counties, UT }\end{array}$ & Mountain & $21-47(12-156)$ \\
\hline 8/Houston (1973) & Yellowstone Park, North Range & Mountain & $17-41(6-60)$ \\
\hline \multirow[t]{2}{*}{ 9/Miller and Heyerdahl 2008} & Northeastern California & Mountain $^{1}$ & $(<25)$ \\
\hline & & Mountain ${ }^{2}$ & $(80-140)$ \\
\hline
\end{tabular}

${ }^{1}$ Sagebrush-Idaho fescue association: fire return interval inferred from presence of mollic soil horizon, deep loamy soil, absence of western juniper (Juniperus occidentalis), high perennial grass cover $(>30 \%)$, and high fuel load $\left(\sim 2000 \mathrm{~kg} \cdot \mathrm{ha}^{-1}\right)$.

${ }^{2}$ Sagebrush-bluebunch wheatgrass association: fire return interval inferred from time since last known fire (60 yr), general absence to weak presence of mollic soil horizons (suggesting grasses did not persist as a dominant component), absence of live old western junipers but scattered snags $>140 \mathrm{yr}$ old, and low fine fuel load $\left(\sim 255 \mathrm{~kg} \cdot \mathrm{ha}^{-1}\right)$.

\section{EVIDENCE OF FIRE HISTORY IN THE GREAT BASIN}

Fire is an ecological catalyst (Pyne 2004), a disturbance process that affects plant succession from small to large scales, depending on the specific event or spatial relationships among multiple events, across time. On sagebrush-bunchgrass rangelands without cheatgrass (Bromus tectorum) and other invasive nonnative weeds, vegetation composition can range from herbaceous- to shrub-dominated, depending on seral stage. The widespread absence of old trees to record fire events in the sagebrush-dominated portions of the Great Basin leaves the fire history across much of the region largely unknown. The few studies conducted have occurred primarily at the interface of mountain big sagebrush communities and conifer trees (Table 4). Their data show MFRIs (for scarring fires) of 6 to $60 \mathrm{yr}$, and a range between scarring fires of 3 to $156 \mathrm{yr}$. Except for the research by Miller and Heyerdahl (2008), none of the other studies in Table 4 or other reviews about fire ecology in the Great Basin (e.g., Wright and Bailey 1982; Bunting et al. 1987) provide quantitative data about fuel loads or fuel continuity in or across sagebrush ecological sites. At best, they speculate that low sagebrush communities, as compared to big sagebrush communities, have much longer return intervals because they produce less biomass. Further, the ignition of most historic fires is often apparently presumed to be lightning. For example, five of the nine references in Table 4 did not mention aboriginal fire. Native American influences prior to Euro-American settlement are largely ignored.

\section{Was the Great Basin Fuel-limited?}

Current and historic empirical data about fuel loads, fuel continuity, and ignition sources are scarce for sagebrushbunchgrass communities. To determine whether sagebrushbunchgrass communities in the Great Basin were fuel-limited before establishment of invasion by the highly flammable cheatgrass and other exotic annual weeds, we can examine information from the few available data sources on fuel loads.
Stebleton and Bunting (2009) presented fuel load data from four Wyoming big sagebrush vegetation groups, with shrub and herbaceous cover above or below 25\%. Two of these groups had minimal cheatgrass cover $(\leq 5 \%)$ and average total fuel loads of 6009 to $11506 \mathrm{~kg} \cdot \mathrm{ha}^{-1}$, with over $90 \%$ of the fuel load from shrubs (predominantly Wyoming sagebrush). Individual subplots $(n=230)$ had herbaceous fuel loads that ranged from 10 to $743 \mathrm{~kg} \cdot \mathrm{ha}^{-1}$. Focusing on annual (yearly) primary production, we summarized production data from sagebrush sites across four Major Land Resource Areas in Nevada (Table 5). We used $674 \mathrm{~kg} \cdot \mathrm{ha}^{-1}$ as a threshold because limited research summarized by Bunting et al. (1987) indicates that this is the amount of annual production necessary to carry a fire. Many low and big sagebrush sites have annual production values above the $674 \mathrm{~kg} \cdot \mathrm{ha}^{-1}$ threshold (Table 5). Shiflet (1994) reported mean annual production ranges of 330 to 750 $\mathrm{kg} \cdot \mathrm{ha}^{-1}$ for low sagebrush communities, and 440 to 775,775 to 2100 , and 1100 to $2750 \mathrm{~kg} \cdot \mathrm{ha}^{-1}$ for Wyoming, basin, and mountain big sagebrush communities, respectively (all without cheatgrass).

For sake of comparison, the ponderosa pine (Pinus ponderosa) region of Arizona and New Mexico provides valuable insight. These forests have the best studied fire history in the United States, with a well-documented MFRI of 6 to $15 \mathrm{yr}$ (Touchan et al. 1996; Fule et al. 2003). Empirical and modeling data indicate an understory herbaceous production of 454 to $1452 \mathrm{~kg} \cdot \mathrm{ha}^{-1}$ annually (Covington and Moore 1994; Covington et al. 1997, 2001). Although the variables of monsoonal weather patterns and accumulated pine needles make comparison imperfect, we are still left with the obvious fact that many sagebrush-perennial grass communities have comparable herbaceous fuel loads, as demonstrated by sagebrush ecological sites in northern Nevada (Table 5). In a northern California study, Miller and Heyerdahl (2008) reported fine fuel loads ranging from 550 to $2359 \mathrm{~kg} \cdot \mathrm{ha}^{-1}$ in mountain big sagebrushIdaho fescue communities.

Potential fuel, however, is more than just the product of annual primary production; rather, it includes standing live vegetation, standing dead vegetation, and surface litter. Rickard 
Table 5. Annual (yearly) vegetation production estimates for big sagebrush and low sagebrush sites in northern and central Nevada, based on data from NRCS (2001) and three undated NRCS ecological site description publications. Ecological site data are for mid-successional plant communities with approximately equal amounts of perennial grasses and shrubs.

\begin{tabular}{l}
\hline Owyhee High Plateau MLRA \\
32 sagebrush sites \\
14 with 674 to $1123 \mathrm{~kg} \cdot \mathrm{ha}^{-1}$ production \\
7 with $>1123 \mathrm{~kg} \cdot \mathrm{ha}^{-1}$ production \\
Malhuer High Plateau MLRA \\
60 sagebrush sites \\
25 with 674 to $1123 \mathrm{~kg} \cdot \mathrm{ha}^{-1}$ production \\
22 with $>1123 \mathrm{~kg} \cdot \mathrm{ha}^{-1}$ production \\
Humboldt MLRA \\
25 sagebrush sites \\
8 with 674 to $1123 \mathrm{~kg} \cdot$ ha $^{-1}$ production \\
6 with $>1123 \mathrm{~kg} \cdot \mathrm{ha}^{-1}$ production \\
Central Nevada Basin and Range MLRA \\
40 sagebrush sites \\
17 with 674 to $1123 \mathrm{~kg} \cdot$ ha $^{-1}$ production \\
8 with $>1123 \mathrm{~kg} \cdot \mathrm{ha}^{-1}$ production \\
\hline
\end{tabular}

${ }^{1}$ MLRA indicates Major Land Resource Area.

and Vaughan (1988) derived values from a 4-yr study in a Wyoming big sagebrush site in south-central Washington (Table 6). Their study site averaged about $21.6 \mathrm{~cm}$ of precipitation and had a mean high temperature in July of $37.6^{\circ} \mathrm{C}$, similar to much of the Great Basin's sagebrush area, and had virtually no cheatgrass. Little other comparable information exists about above-ground biomass components for most sagebrush ecological sites. Data from Table 6 show that annual primary production is a small part of the total fuel on a sagebrush ecological site, but a value that is readily measured or available from ecological site descriptions. For utilitarian purposes, dividing 1 by the collective live : total fuel ratio (0.177) from Table 6 calculates a multiplier of 5.6 that could be used to estimate total fuel load for a given site if annual production is known. The specific multiplier undoubtedly varies, depending on the herbaceous : shrub ratio, but this example clearly demonstrates that total fuel load is from several to many times annual primary production. These data suggest that, even without a cheatgrass component, most sagebrush rangelands, including many low sagebrush sites, have adequate fuel loads to burn more frequently than 70 to $450 \mathrm{yr}$ (the range estimated by Baker 2006). Even the drier Wyoming sagebrush ecological sites are subject to great fuel load variability.

Low sagebrush sites, in particular, have been reported to burn very infrequently because of fuel sparseness, especially soon after a fire. Virtually no data exists for low sagebrush sites regarding biomass accumulation across time. The authors have photographic documentation for three large, dispersed northern Nevada rangeland fires that, across years and locations, included numerous interspersed low sagebrush communities that were fire-impacted since 1999 (Figs. S1-S4; available online at http://dx.doi.org/10.2111/REM-D-11-00231.s1). All of these sites were on landforms with little $(<15 \%)$ or no slope, and none of the fires were cheatgrass-driven. Apparently,
Table 6. Weight of herbaceous and shrub fuel components, based on end of growing season data, on a Wyoming big sagebrush site in south-central Washington (adapted from Rickard and Vaughan 1988).

\begin{tabular}{lrr}
\hline \multicolumn{1}{c}{ Plant part ${ }^{1}$} & $\mathrm{~g} \cdot \mathrm{m}^{-2}$ & $\mathrm{~kg} \cdot \mathrm{ha}^{-1}$ \\
\hline Herbaceous & & \\
Live shoot & 58 & 580 \\
Standing dead & 84 & 840 \\
Grass crowns & 99 & 830 \\
Litter & 153 & 1530 \\
Total & 395 & 3950 \\
Shrub & & \\
Leaves & 8 & 80 \\
Live wood & 28 & 280 \\
Dead wood & 43 & 430 \\
Woody litter & 57 & 570 \\
Total & 136 & 1360 \\
\hline${ }^{1}$ Live shoot: total ratio=0.147. Live (leaves + wood) : total ratio $=0.265$. Collective live: total \\
$\quad$ ratio=0.177.
\end{tabular}

fires in low sagebrush communities interspersed within big sagebrush-dominated landscapes are not rare when fuel loads have reached a minimum (largely unknown) threshold. Most likely, sustained winds, high temperatures, several consecutive wet years that allow accumulation of fine fuels, and low relative humidity interact with fuels and topography to drive many fires when fine fuels are not high (Riegel et al. 2006).

If fires can readily burn large areas with relatively low annual primary production, even without cheatgrass, the question becomes: how many years are required before there is enough biomass for a fire to potentially re-occur? The answer would provide some insight into the potential fire frequency prior to Euro-American settlement and the initiation of widespread, intensive livestock grazing. Very little published information exists about biomass production across time in the hundreds of sagebrush ecological sites found in the sagebrush biome. The authors have additional photographic documentation of substantial native perennial herbaceous fuel loads and connectivity 2 to 6 yr after fire in four locations, within predominantly Wyoming big sagebrush ecological sites, representing three northern Nevada wildfires that burned in two separate years (Figs. S5-S9; available online at http://dx.doi.org/10.2111/ REM-D-11-00231.s1). The information summarized for sagebrush sites in Table 5, along with these photographs, suggests the potential to produce perennial herbaceous fuels with adequate biomass and continuity for relatively frequent reburns, assuming the presence of ignition sources. Snow-loads in most winters cause erect stems to become prostrate fuel, substantially increasing connectivity at multiple scales in and across ecological sites. Before the introduction of domestic livestock herds that had the potential to reduce fuel loads (Burkhardt and Tisdale 1976; Davies et al. 2010), there had not been large herds of native ungulates to perform an equivalent fuel reduction function since possibly the early Holocene 7000 to 8000 yr before present (Burkhardt 1996). Obviously, based on annual primary production, fuel load, and fuel continuity potential, Great Basin sagebrush-perennial grass communities, even before the accidental introduction of cheatgrass, were not fuel-limited. In fact, if herbaceous production during the LIA 
was indeed greater than today (Wigand et al. 1995), our calculations may be underestimations.

\section{Was the Great Basin Ignition-limited?}

The anecdotal accounts (summarized in Tables 2 and 3) from anthropologists and early explorers indicate widespread use of fire by aboriginals for multiple reasons. The language used in the descriptions suggests some fires were relatively large, multiple fires were often set, and grass was an abundant fuel, especially in higher elevations dominated by mountain big sagebrush. Although some native bunchgrasses, especially the broad-leaf species, may respond positively to cool season fire in the short-term through increased reproduction and high survival rates in mountain big sagebrush sites (Ellsworth and Kauffman 2010), it cannot be stated categorically that this characteristic overwhelmingly reinforces the concept of relatively frequent burns. However, many herbaceous species in sagebrush communities are adapted to fire (Miller and Eddleman 2001), with cover of several deep-rooted species recovering to preburn levels within 2 to $3 \mathrm{yr}$ after fire (Miller et al. in press). These species include bluebunch wheatgrass (Pseudoroegnaria spicata; Blaisdell 1953; Conrad and Poulton 1966; Uresk et al. 1976, 1980; Hosten and West 1994), bottlebrush squirreltail (Elymus elymoides; Wright and Klemmedson 1965; Young and Miller 1985; Blank et al 1994; Bates et al. 2009), Columbia needlegrass (Achnatherum lemmonii; Baisdell 1953), and basin wildrye (Leymus cinereus; Everett and Ward 1984; Young 1987). Fine-leaf grasses such as Idaho fescue (Festuca idahoensis) and Thurber's needlegrass (Achnatherum thurberianum) are more sensitive to fire, suffering greater crown mortality and slower recovery rates than broad-leaf grasses (Blaisdell 1953; Wright 1971). However, both of these species can recover on more moist sites, with biomass and cover exceeding preburn levels within 3 to $5 \mathrm{yr}$ after fall-applied prescribed fire (Davies et al. 2008; Bates et al. 2009).

Although forb species are variously impacted by fire, perennial forb production generally increases 2 to $3 \mathrm{yr}$ after fire in more mesic sagebrush communities (Blaisdell 1953; Wrobleski and Kauffman 2003), but is less responsive in more xeric sagebrush communities (Blaisdell 1953; Bunting et al. 1987; Fischer et al. 1996; Riegel et al. 2006). Fire ignition timing affects perennial grass response (Wright and Bailey 1982; Bunting et al. 1987; Davies et al. 2007; Seefeldt et al. 2007; Davies et al. 2008). In the Great Basin, the cool season grasses that dominate this area are in general least detrimentally affected by fall burning (Bunting et al. 1987), but few studies have been done and variable results have likely been influenced by fire severity (Miller et al. in press). Cool season burns (especially fall) were commonly conducted by aboriginals, as mentioned earlier.

Much of the sagebrush region has fewer than $30 \mathrm{~d}$ of lightning per year, and many areas have less than $20 \mathrm{~d}$ (Houghton et al. 1975). The fire return interval, however, is very similar for southeast Oregon in the Great Basin (Miller and Rose 1999; Miller et al. 2001) and the ponderosa pine forests of Arizona and New Mexico where lightning occurs 60 or more days annually (USDOE 1979). This implies several possibilities with regard to pre-Euro-American settlement fires:
1) few days of lightning were needed to start most of the fires that burn a landscape when fires are not controlled; 2) additional ignition sources (i.e., anthropogenic) were present; 3) some fires were very large; or 4) a combination of the above.

Recent empirical information based on fire regime history reconstructed from tree rings (Kitchen 2010) has provided credible evidence of consequential anthropogenic fire ignitions in the eastern Great Basin. Results showed that early and late season fires, preferred times of intentional burning by Indians as mentioned previously, were more common between 1400 and $1900 \mathrm{CE}$ than those during mid-season, the time during which lightning fires peak.

One aspect of fire largely overlooked by early explorers, ethnographers, and modern ecologists is escaped campfires. Native cultures apparently lacked the social pressure to extinguish fires, and many prehistoric campfires undoubtedly escaped (Stewart 1956), burning small to very large areas. In an article comparing aboriginal and lightning ignition rates in the United States, Kay (2007) estimated, based on a series of conservative assumptions, including the lowest population estimates for aboriginal populations in the Great Basin, that the aboriginal ignition rate in this region could easily have been 10 times the known lightning ignition rate. Adding in purposefully set aboriginal landscape fires, Kay (2007) maintained that the differential would actually have been much higher. Kay's calculations support the assertions made originally by Stewart $(1956,1963,2002)$, and now echoed by many others that aboriginal ignitions probably overwhelmed lightning ignitions. Obviously, Great Basin sagebrush-perennial grass communities were not ignition-limited before EuroAmerican settlement.

\section{Aboriginal- vs. Lightning-Caused Fires}

According to Arno (1985), fires set by aboriginals augmented lightning ignitions, reducing the average intervals between fires in many grassland, shrubland, and dry forest vegetation types. $\mathrm{He}$ also indicated that aboriginal ignitions may date back 500 to $2000 \mathrm{yr}$ in parts of the West. "Fires set by hunter-gatherers differ from (lightning) fires in terms of seasonality, frequency, intensity, and ignition patterns" (Lewis 1985, p. 75). Reviewing literature for detail about the characteristics of purposefully set aboriginal fires, Kimmerer and Lake (2001) came to similar conclusions, also noting that the extent of purposely set fires was typically modest in size and the specific sites burned depended on food and material needs.

Regarding fire frequency, Kay (1998) concluded that frequent burning by Native Americans produced a higher frequency of low-intensity fires, as compared to lightning fires that typically are less frequent and of higher intensity. The vegetation mosaics created by aboriginals likely reduced the effects of high intensity, lightning-generated fires (Reid et al. 1989; Pyne 1993, 1995). Using a state-and-transition-based model to simulate successional trajectories in sagebrush ecosystems, Evers et al. (2013) found that increasing the probability of mosaic fire reduced the fire rotation interval in mountain big sagebrush communities. Kimmerer and Lake (2001, p. 38) concluded that "the most important outcome of fire use was the intentional creation of a mosaic of habitat patches that promoted food security by ensuring a diverse and 
productive landscape," with diverse habitats buffering the impact of natural fluctuation in a single food species and increasing overall productivity. Aboriginally set fires also had irregular burn margins, a phenomenon that accentuated the mosaic pattern. Modern fires often stop at roads or fire lines, which are unusually straight or smooth compared to natural fire margins that more often burn to a difference in fuel structure. Once Native Americans opened up the vegetation and produced fuel loading variability, subsequent lightning fires behaved more like those set by the aboriginals (Pyne 1993, 1995; Kay 1998). Taking a more moderate stance, Vale (2002, p. 298) concluded that "The pre-European landscape in the American West was a mosaic: some areas were altered by the activities of native peoples, including increased burning, and some areas were molded by natural processes." According to Christensen (1991), "In areas where fire exclusion strategies have altered fuel conditions, fire behavior may be considerably different than on pre-European contact landscapes.”

\section{EXTRAPOLATION FOR CONTEMPORARY ECOLOGICAL CONTEXT}

In recent years, both anthropologists and ecologists have warned about the dangers of ignoring historic human impacts as a component of ecological variability (Swetnam et al. 1999; Griffin 2002). This review of literature demonstrably illustrates the active participation of aboriginal Native Americans in the vegetation management of at least major portions of the sagebrush ecosystem in the Great Basin. Integrating inferences from fire-scar history, a comparison of prehistoric humanignited fires vs. lightning-caused fires, and annual production capability in sagebrush-perennial grass ecological sites, we suggest that prehistoric environmental conditions in the Great Basin were neither fuel- nor ignition-limited. Rather, a "big picture" emerges of relatively widespread and common burning that affected much of the landscape.

The authors acknowledge that contemporary application of prescribed burning to sagebrush-grass communities in a carte blanche manner to simulate aboriginal application would be disastrous. Nevertheless, we suggest that, based on aboriginal precedent, current historically unprecedented conditions (fuel load and exotic weed invasion threats), and predicted climate change, active management of sagebrush-grass communities is paramount. Such active management has also been strongly inferred (Young et al. 1979) or directly proposed by others (Wisdom et al. 2002; Kitchen 2010; Davies et al. 2011b). However, Davies et al. (2009) noted that returning ecosystems to historical or pre-Euro-American settlement conditions by reintroducing historical disturbance may be impractical. Rather, the authors maintained that objectives for ecosystem management should be focused on specific measurable goals that society has determined are valuable (e.g., soil stability, biodiversity, wildlife habitat, forage production, etc.). Balancing ecological principles with society's demands for resource production and sustainability is becoming the mandate (Keane et al. 2009). According to Griffin (2002, p. 95), "Better understanding of past human manipulations in the northern Intermountain West may allow us to understand better its regional ecology as it continues to organize itself in the context of biophysical conditions and constraints that have never before existed."

Obviously, in light of contemporary cheatgrass invasion and conifer encroachment of sagebrush communities, current management is not producing desirable results over much of our sagebrush-dominated landscapes. Sustained active management of sagebrush-perennial grass communities is necessary, along with passive management to maintain treated areas. Such active management typically involves sagebrush reduction to set back succession to an earlier seral stage, removal of encroaching conifers, and/or seeding/planting desirable vegetation. Obviously, treatment size must also be carefully considered when working within critical wildlife habitat (Connelly et al. 2000; Beck et al. 2012). Because prescribed fire is not always ecologically appropriate or judicious, especially in Wyoming big sagebrush communities (Beck et al. 2012), managers should be prepared to use other alternatives. Though certainly not fire surrogates in the strictest sense, mechanical, herbicidal, and/or biological substitutes (Roundy 2005; Davies et al. 2011; Beck et al. 2012; Miller et al. in press) might be appropriate measures site-specifically where low severity disturbance is deemed appropriate.

Detailed comparison of these treatments is beyond the scope of this paper, but it is important to note that each has site/situation-specific advantages and disadvantages. For example, the mechanical removal of conifers during early to mid-succession stages of encroachment may be preferred in order to reduce the chance of exotic annual grass invasion that fire could bring (Davies et al. 2011b; Beck et al. 2012). Mechanical reduction of sagebrush by mowing has the advantages of leaving small sagebrush plants (Davies et al 2009), residual debris used for cover by wildlife (Dahlgren et al. 2006), and is easily controlled for application to smaller areas (Hess and Beck 2012). However, mechanical treatment of sagebrush is often a high-risk strategy in Wyoming big sagebrush communities, enhancing the potential for invasion of exotic annual grasses (Davies et al. 2011a). The comparative benefits and detriments of chemical treatments are a function of ecological site and specific herbicide used (Miller et al. 1980; Dahlgren et al. 2006; Beck et al. 2012). Strategic grazing may be used to reduce fuel loads and continuity (Davies et al. 2010, 2011b), and targeted grazing can be an effective tool to reduce exotic grass cover (Diamond et al. 2009), but timing and animal control are essential to reduce damage to desirable plant species. According to Crawford et al. (2004, p. 14), "Active management will likely be required to address the problem of annual grass invasion ... a dilemma for which there is not currently a definitive solution over large scales." Although the current trend is to treat areas already dominated by cheatgrass, we submit that active management that addresses the prevention of cheatgrass invasion into sagebrush-perennial grass rangelands is the most practical and economical.

\section{MANAGEMENT IMPLICATIONS}

Regarding the contemporary use of prescribed fire, extreme caution is always mandatory. "A century or more of fire 
suppression in many ecosystems, in addition to an abundance of nonnative species in some landscapes, now makes it difficult to predict successional trajectories of communities after fires" (Pyke et al. 2010, p. 274). Because of our contemporary situation with the threat of exotic weed invasions, severe disturbances should be minimized (Sheley et al. 1999). However, intentionally applied low severity disturbances can serve to increase the capacity for intact sagebrush-perennial grass communities to be more resistant to exotic weed invasion in the long term and resilient after severe (e.g., wildfire) disturbances (Davies et al. 2008, 2009). Such active management is more appropriate in cool soil/higher soil moisture regimes, typically in higher elevations dominated by mountain big sagebrush communities (Seefeldt et al. 2007; Evers et al. 2013; Miller et al. in press) where postfire recovery rates are more rapid (Miller et al. 2001; Miller et al. in press) and the herbaceous component of a healthy intact community can return to prefire conditions within 3 yr postfire (Seefeldt 2007). Although some Wyoming big sagebrush communities fall within this cool soil/higher soil moisture regime, most Wyoming big sagebrush communities are at lower elevations within the warm soil/lower soil moisture regime and are more severely affected by disturbance (Miller et al. in press), requiring 25 to 100 yr for complete recovery (Baker 2011). Accordingly, associated wildlife species in these drier Wyoming big sagebrush sites can be negatively impacted by well-intended treatments (Beck et al. 2012).

In terms of contemporary active management, we think that emphasis should be placed on actions that are required to achieve ecological resilience and functionality. Bestelmeyer and Briske (2012, p. 654) concluded that future management of rangelands should be resilience-based to ensure sustainability of ecosystem services in an era of rapid change; such management would include directing trajectories of ecosystem change. In sagebrush-bunchgrass communities, invasion resistance and successional resilience are functions of a healthy bunchgrass component. More specifically, resistance of sagebrush communities to invasion by exotic weeds is directly correlated to perennial grass density (Roundy 2005; Chambers et al. 2007; Davies et al. 2008; Davies et al. 2011b), although the other functional groups are also important competitors that decrease invasibility (James et al. 2008). Active management may be necessary to: 1 ) improve site resiliency by restoring the perennial herbaceous understory that will lead to recovery after fire and/or 2) reduce fuel load and continuity to decrease size and intensity of wildfire events. Successional management of rangeland plant communities has been validated as a means to address exotic plant invasions and plant community restoration (Sheley et al. 2010). Widespread physical disturbance was an ecological driver in sagebrush-grass ecosystems prior to EuroAmerican settlement, and sagebrush communities remain disturbance-driven (Crawford et al. 2004; Seefeldt et al. 2007; Evers et al. 2013). Complete or near-complete removal of physical disturbance from these systems in and of itself constitutes a major disturbance. Alternately, if thoughtful active management is not applied, the status quo of predominantly passive management will result in successional changes that lead to permanent undesired vegetation (e.g., exotic weed monocultures or conifer encroachment) over vast acreages. Since pre-Columbian times, mankind has played a role in shaping landscapes in North America (McCann 1999b). Contemporary challenges require that we learn from the past and judiciously adapt best management practices to address ecosystem health and functionality into the future.

\section{ACKNOWLEDGMENT}

The senior author thanks Dr James A. Young (retired range scientist, USDA-ARS) for teaching by example the importance of historical information in interpreting ecological interrelationships.

\section{LITERATURE CITED}

Anderson, M. K. 2002. An ecological critique. In: 0. C. Stewart [Author]. Forgotten fires: Native Americans and the transient wilderness. Norman, OK, USA: University of Oklahoma Press. p. 37-64.

Anderson, M. K. 2005. Tending the wild: Native American knowledge and the management of California's natural resources. Berkeley, CA, USA: University of California Press. 526 p.

Arno, S. F. 1985. Ecological effects and management implications of Indian fires. In: J. E. Lotan, W. C. Fischer, and W. R. Mutch [TECH. COORDS.]. Proceedings: Symposium and Workshop on Wilderness Fire; 15-18 November 1983; Missoula, MT, USA. Ogden, UT, USA: USDA Forest Service Intermountain Forest and Range Experiment Station. General Technical Report INT-182. p. 81-86.

Arno, S. F., and G. E. Gruell. 1983. Fire history at the forest-grassland ecotone in southwestern Montana. Journal of Range Management 36:332-336.

BAKER, W. L. 2006. Fire and restoration of sagebrush ecosystems. Wildlife Society Bulletin 34:177-185.

BAKER, W. L. 2011. Pre-Euro-American and recent fire in sagebrush ecosystems. Studies in Avian Biology 38:185-201.

Bates, J. D., E. C. Rhodes, K. W. Davies, and R. Sharp. 2009. Postfire succession in big sagebrush steppe with livestock grazing. Rangeland Ecology \& Management 62:68-110.

Beck, J. L., J. W. Connelly, and C. L. Wambolt. 2012. Consequences of treating big sagebrush to enhance wildlife habitats. Rangeland Ecology \& Management 65:444-455.

Bestelmeyer, B. T., And D. D . Briske. 2012. Grand challenges for resilience-based management of rangelands. Rangeland Ecology \& Management 65:654-663.

BLAISDELL, J. P. 1953. Ecological effects of planned burning of sagebrush-grass range on the upper Snake River Plains. Washington, DC, USA: USDA. Technical Bulletin 1075. 39 p.

Blank, R. B., F. Allen, and J. A. Young. 1994. Extractable anions in soils following wildfire in a sagebrush-grass community. Soil Science Society of America Journal 58:564-570.

BotKIN, D. B. 1990. Discordant harmonies: a new ecology for the twenty-first century. New York, NY, USA: Oxford University Press. 256 p.

BoYd, R. 1986. Strategies of Indian burning in the Williamette Valley. Canadian Journal of Anthropology 5:65-86.

Bunting, S. C., B. M. KILgoRE, AND C. L. Bushey. 1987. Guidelines for prescribed burning sagebrush-grass rangelands in the northern Great Basin. Ogden, UT, USA: USDA Forest Service Intermountain Research Station. General Technical Report INT231. $33 \mathrm{p}$.

BuRKHARDt, J. W. 1996. Herbivory in the Intermountain West. Moscow, ID, USA: University of Idaho. Idaho Forest, Wildlife, and Range Experiment Station Bulletin 58. $18 \mathrm{p}$.

Burkhardt, J. W., and E. W. Tisdale. 1976. Causes of juniper invasion in southwestern Idaho. Ecology 57:472-484.

Chambers, J. C., B. A. Roundy, R. B. Blank, S. E. Meyer, and A. Whittaker. 2007. What makes Great Basin sagebrush ecosystems invasible by Bromus tectorum? Ecological Monographs 77:117-145.

Christensen, N. L. 1991. Wilderness and high intensity fire: how much is enough? In: S. M. Hermann [ED.]. Proceedings of the 17th Tall Timbers Fire Ecology 
Conference: high intensity fire in wildlands management-challenges and options; 18-21 May 1989; Tallahassee, FL, USA. Tallahassee, FL, USA: Tall Timbers Research Station. p. 9-24.

Connelly, J. W., M. A. Schroeder, A. R. Sands, and C. E. Braun. 2000. Guidelines to manage sage-grouse populations and their habitats. Wildlife Society Bulletin 28:967-985.

Conrad, C. E., and C. E. Poulton. 1966. Effect of a wildfire on Idaho fescue and bluebunch wheatgrass. Journal of Range Management 19:138-141.

Covington, W. W., P. Z. Fule, S. C. Hart, and R. P. Weaver. 2001. Modeling ecological restoration effects on ponderosa pine forest structure. Restoration Ecology 9:421-431.

Covington, W. W., P. Z. Fule, M. M. Moore, S. C Hart, T. Kolb, J. Mast, S. S. Sackett, AND M. R. WANGER. 1997. Restoring ecosystem health in ponderosa pine forests of the Southwest. Journal of Forestry 95:23-29.

Covington, W. W., AND M. M. Moore. 1994. Southwestern ponderosa forest structure: changes since Euro-American settlement. Journal of Forestry 92:39-47.

Crawford, J. A., R. A. Olson, N. E. West, J. C. Mosley, M. A. Schroeder, T. D. Whitson, R. F. MIlleer, M. A. GREGG, AND C. S. Boyd. 2004. Ecology and management of sage-grouse and sage-grouse habitat. Journal of Range Management 57:2-19.

Dahlgren, D. K., R. Chi, and T. A. Messmer. 2006. Greater sage-grouse response to sagebrush management in Utah. Wildlife Society Bulletin 34:975-985.

DaubenmiRe, R. F. 1942. An ecological study of the vegetation of southeastern Washington and adjacent Idaho. Ecological Monographs 12:53-79.

Davies, K. W., J. D. Bates, and R. F. Miller. 2007. Short-term effects of burning Wyoming big sagebrush steppe in southeast Oregon. Rangeland Ecology \& Management 60:515-522.

Davies, K. W., J. D. Bates, and A. M. Nafus. 2011a. Are there benefits to mowing Wyoming big sagebrush plant communities? An evaluation in southeastern Oregon. Environmental Management 48:539-546.

Davies, K. W., J. D. Bates, T. J. Svejcar, and C. S. Boyd. 2010. Effects of long-term livestock grazing on fuel characteristics in rangelands: an example from the sagebrush steppe. Rangeland Ecology \& Management 63:662-669.

Davies, K. W., C. S. Boyd, J. L. Beck, J. D. Bates, T. J. Svejcar, and M. A, Gregg. 2011b. Saving the sagebrush sea: an ecosystem conservation plan for big sagebrush plant communities. Biological Conservation 144:2573-2584.

Davies, K. W., R. L. Sheley, and J. D. Bates. 2008. Does fall prescribed burning Artemisia tridentata steppe promote invasion resistance to invasion after a recovery period? Journal of Arid Environments 72:1076-1085.

Davies, K. W., T. J. Svejcar, and J. D. Bates. 2009. Interaction of historical and nonhistorical disturbances maintains native plant communities. Ecological Applications 19:1536-1545.

Diamond, J. M., C. A. Call, And N. Devoe. 2009. Effects of targeted cattle grazing on fire behavior of cheatgrass-dominated rangeland in the northern Great Basin, USA. International Journal of Wildland Fire 18:944-950.

DruCKer, P. 1941. Culture element distribution studies: XVII, Yuman-Piman. University of California Anthropological Records 6:91-230.

Ellsworth, L. M., AND J. B. Kauffman. 2010. Native bunchgrass response to prescribed fire in ungrazed mountain big sagebrush ecosystems. Fire Ecology 6(3):86-96.

EVERETT, R. L., AND K. WARD. 1984. Early plant succession in pinyon-juniper controlled burns. Northwest Science 58:57-68.

Evers, L. B., R. F. Mlller, P. S. Doescher, M. Hemstrom, and R. P. Nellson. 2013. Simulating current successional trajectories in sagebrush ecosystems with multiple disturbances using a state-and-transition modeling framework. Rangeland Ecology \& Management 66:313-329.

Fischer, R. A., K. P. Reese, and J. W. Connelly. 1996. An investigation on fire effects within xeric sage grouse brood habitat. Journal of Range Management 49:194198.

Fowlek, C. 1986. Subsistence. In: W. D'Azavedo [ED.]. Handbook of American Indians, Vol. 11: Great Basin. Washington, DC, USA: Smithsonian Institution. $p$. 64-97.

Fule, P. Z., T. A. Heinlein, And W. W. Covington. 2006. Fire histories in ponderosa pine forests of Grand Canyon are well supported: reply to Baker. International Journal of Wildland Fire 15:439-455.

Fule, P. Z., T. A. Heinlein, W. W Covington, and M. M. Moore. 2003. Assessing fire regimes on Grand Canyon landscapes with fire-scar and fire-record data. International Journal of Wildland Fire 12:129-145.
GotTESFELD, L.M.J. 1994. Aboriginal burning for vegetative management in northwest British Columbia. Human Ecology 22:171-188.

GrifFin, D. 2002. Prehistoric human impacts on fire regimes and vegetation in the northern Intermountain West. In: T. R. Vale [ED.]. Fire, native peoples, and the natural landscape. Washington, DC, USA: Island Press. p. 77-100.

GrueLL, G. E. 1985. Fire on the early western landscape: an annotated record of wildland fires 1776-1900. Northwest Science 59:97-107.

GrueLL, G. E. 1996. Influence of fire on Great Basin wildlife habitats. Transactions of the Western Section of The Wildlife Society 32:55-61.

GRUELL, G. E. 1999. Historic and modern roles of fire in pinyon-juniper woodlands. In: S. B. Monsen and R. Stevens [comps.]. Proceedings: Ecology and Management of Pinyon-Juniper Communities within the Interior West; 15-18 September 1997; Provo, UT, USA. Ogden, UT, USA: USDA Forest Service Rocky Mountain Research Station. Proceedings RMRS-P-9. p. 24-28.

Gruell, G. E., AND S. R. Swanson. 2012. Nevada's changing wildlife habitat: an ecological history. Reno, NV, USA: University of Nevada Press. 178 p.

HarpeR, K. T. 1986. Historical environments. In: W. D'Azavedo [ED.]. Handbook of American Indians, Vol. 11: Great Basin. Washington, DC, USA: Smithsonian Institution. p. 51-63.

Hess, J. E., AND J. L. BECK. 2012. Burning and mowing Wyoming big sagebrush: do treated sites meet minimum guidelines for greater sage-grouse breeding habitats? Wildlife Society Bulletin 36:85-93.

Heyerdahl, E. K., R. F. Mlller, and R. A. Parsons. 2006. History of fire and Douglas-fir establishment in a savanna and sagebrush-grassland mosaic, southwestern Montana, USA. Forest Ecology and Management 230:107-118.

Hosten, P. E., AND N. E. West. 1994. Cheatgrass dynamics following wildfire on a sagebrush semidesert site in central Utah. In: S. B. Monsen and S. G. Kitchen [EDS.]. Proceedings: Ecology and Management of Annual Rangelands; 18-21 May 1992; Boise, ID, USA. Ogden, UT, USA: USDA Forest Service Intermountain Forest and Range Experiment Station. INT-GTR-313. p. $56-62$.

Houghton, J. G., C. M. Sakamoto, and R. 0. Gifford. 1975. Nevada's weather and climate. Reno, NV, USA: University of Nevada Reno Mackay School of Mines. Nevada Bureau of Mines and Geology Special Publication 2. 84 p.

Houston, D. D. 1973. Wildfires in northern Yellowstone National Park. Ecology 54:1109-1117.

HuLl, A. C., JR., AND M. K. HuLl. 1974. Pre-settlement vegetation of Cache Valley Utah and Idaho. Journal of Range Management 27:27-29.

James, J. J., K. W. Davies, R. L. Sheley, and Z. T. Aanderud. 2008. Linking nitrogen partitioning and species abundance to invasion resistance in the Great Basin. Oecologia 156:637-648.

KAY, C. E. 1995. Aboriginal overkill and native burning: implications for modern ecosystem management. Western Journal of Applied Forestry 10:121-126.

Kay, C. E. 1998. Are ecosystems structured from the top-down or bottom-up? A new look at an old debate. Wildlife Society Bulletin 26:484-498.

KAY, C. E. 2007. Are lightning fires natural? A comparison of aboriginal and lightning rates in the United States. In: R. E. Masters and K. E. M. Galley [Eds.]. Proceedings of the 23rd Tall Timbers Fire Ecology Conference: fire in grassland and shrub ecosystems; 17-20 October 2005; Bartlesville, OK, USA. Tallahassee, FL, USA: Tall Timbers Research Station. p. 9-24.

Keane, R. E., P. F. Hessburg, P. B. Landres, and F. J. Swanson. 2009. The use of historical range and variability (HRV) in landscape management. Forest Ecology and Management 258:1025-1037.

KeELEY, J. E. 2002. Native American impacts on fire regimes of the California coastal ranges. Journal of Biogeography 29:303-320.

Kelly, I. T. 1932. Ethnography of the Surprise Valley Paiute. University of California Publications in American Archeology and Ethnology 31:67-210.

Kimmerer, R. W., and F. K. Lake. 2001. The role of indigenous burning in land management. Journal of Forestry 2001:36-41.

Kitchen, S. G. 2010. Historic fire regimes of eastern Great Basin (USA) mountains: reconstruction from tree rings [PhD dissertation]. Provo, UT, USA: Brigham Young University. $166 \mathrm{p}$.

KLEBENOW, D. A. 2001. Enhancing sage-grouse habitat: a Nevada landowner's guide. Reno, NV, USA: Nevada Wildlife Federation, Inc. Northwest Sage-grouse Working Group Publication. $13 p$. 
LewIs, H. T. 1973. Patterns of Indian burning in California: ecology and ethnohistory. Ramona, CA, USA: Ballena Press. Anthropological Papers No. 1. 101 p.

LewIS, H. T. 1985. Why Indians burned: specific versus general reasons. In: J. E. Lotan, W. C. Fischer, and W. R. Mutch [TECH. COORDS.]. Proceedings: Symposium and Workshop on Wilderness Fire; 15-18 November 1983; Missoula, MT, USA. Ogden, UT, USA: USDA Forest Service Intermountain Forest and Range Experiment Station. General Technical Report INT-182. p. 75-80.

Matheney, R. T., T. S. Smith, and D. G. Matheney. 1997. Animal ethology reflected in the rock art of Nine Mile Canyon, Utah. Journal of California and Great Basin Anthropology 19:70-103.

McCann, J. M. 1999a. Before 1492-the making of the pre-Columbian landscapePart I: the environment. Ecological Restoration 17:15-30.

McCann, J. M. 1999b. Before 1492-the making of the pre-Columbian landscapePart II: the vegetation, and implications for restoration for 2000 and beyond. Ecological Restoration 17:107-119.

Mensing, S., S. Livingston, and P. Barker. 2006. Long-term fire history in Great Basin sagebrush reconstructed form macroscopic charcoal in spring sediments, Newark Valley, Nevada. Western North American Naturalist 66:64-77.

Mlller, R. F., C. Baisan, J. Rose, and D. Pacioretty. 2001. Pre- and post-settlement fire regimes in mountain big sagebrush steppe and aspen: the northwestern Great Basin. Final Report 2001 to the National Interagency Fire Center. Burns, OR, USA: Eastern Oregon Agricultural Research Center, Oregon State University. 28 p.

Miller, R. F., J. D. Bates, T. J. Svejcar, F. B. Pierson, and L. E. Eddleman. 2005. Biology, ecology, and management of western juniper (Juniperus occidentalis). Corvallis, OR, USA: Oregon State University Agricultural Experiment Station. Technical Bulletin 152. $77 \mathrm{p}$.

Miller, R. F., J. C. Chambers, D. A. Pyke, F. B. Pierson, and C. J. Williams. (in press). Fire effects on vegetation and soils in the Great Basin Region: response and site characteristics. Boise, ID, USA: USDA Forest Service Rocky Mountain Research Station Research. Paper RMRS-RP-\#. 125 p.

Miller, R. F., AND L. L. EdDleman. 2001. Spatial and temporal changes of sage-grouse habitat in the sagebrush biome. Corvallis, OR, USA: Oregon State University Agricultural Experiment Station. Technical Bulletin 151. $35 \mathrm{p}$.

Miller, R. F., R. R. Findley, and J. Alderfer-Findley. 1980. Changes in mountain big sagebrush habitat types following spray release. Journal of Range Management 33:278-281.

Miller, R. F., AND E. K. HeYerdahl. 2008. Fine-scale variation of historical fire regimes in sagebrush-steppe and juniper woodland: an example from California, USA. International Journal of Wildland Fire 17:245-254.

Miller, R. F., S. T. Knick, D. A. Pyke, C. W. Menke, S. F. Hanser, M. W. Wisdom, and A. L. HILD. 2011. Characteristics of sagebrush habitats and limitations to long-term conservation. Studies in Avian Biology 38:145-184.

MilleR, R. F., AND J. A. Rose. 1995. Western juniper expansion in eastern Oregon. Great Basin Naturalist 55:37-45.

Mlllek, R. F., AND J. A. Rose. 1999. Fire history and western juniper encroachment in sagebrush steppe. Journal of Range Management 52:550-559.

[NRCS] Natural Resources Conservation Service. 2001. Ecological site descriptions. Major Land Resource Area 23. Malhuer High Plateau. Reno, NV, USA: USDANRCS. 240 p.

NRCS. Undated. Ecological site descriptions. Major Land Resource Area 24. Humboldt Area. Reno, NV, USA: USDA-NRCS. $384 \mathrm{p}$.

NRCS. UnDATED. Ecological site descriptions. Major Land Resource Area 25. Owyhee High Plateau. Reno, NV, USA: NRCS. 560 p.

NRCS. UndATED. Ecological site descriptions. Major Land Resource Area 28. Central Nevada Basin and Range. Reno, NV, USA: USDA-NRCS. 667 p.

PalGe, C., AND S. A. RitTer. 1999. Birds in a sagebrush sea: managing sagebrush habitats for bird communities. Boise, ID, USA: Partners in Western Flight Working Group. 46 p.

PIPPIN, L. C. 1979. Bighorn sheep and Great Basin prehistory. In: D. R. Touhy and D. L. Rendall [EDS.]. The Archaeology of Smith Creek Canyon, Eastern Nevada. Nevada State Museum Anthropological Paper No. 17. p. 332-358.

Pyke, D. A., M. L. Brooks, And C. D'Antonio. 2010. Fire as a restoration tool: a decision framework for predicting the control or enhancement of plants using fire. Restoration Ecology 18:274-284.

PynE, S. J. 1982. Fire in America: a cultural history of wildland and rural fire. Princeton, NJ, USA: Princeton University Press. 654 p.
Pyne, S. J. 1993. Keeper of the flame: a survey of anthropogenic fire. In: P. J. Crutzen and J. G. Goldammer [EDS.]. Fire in the environment: its ecological, climate, and atmospheric chemical importance. New York, NY, USA: John Wiley and Sons. p. 245-266.

Pyne, S. J. 1995. Vestal fires and virgin lands: a reburn. In: J. K. Brown, R. W. Mutch, and R. H. Wakimoto [EDs.]. Proceedings: Symposium on Fire in Wilderness and Park Management; 30 March-1 April 1993; Missoula, MT, USA. Ogden, UT, USA: USDA Forest Service Intermountain Research Station. General Technical Report INT-320. p. 15-21.

PYNE, S. J. 2004. Tending fire: coping with America's wildland fires. Washington, DC, USA: Island Press. $256 \mathrm{p}$.

ReEd, W. J. 2006. A note on fire frequency concepts and definitions. Canadian Journal of Forest Research 36:1884-1888.

Reid, K. C., J. A. Draper, and P. E. Wigand. 1989. Prehistory and paleoenvironments of the Silvies Plateau, Harney Basin, southeastern Oregon. Pullman, WA, USA: Washington State University Center for Northwest Anthropology. Project Report 8. $258 \mathrm{p}$.

Rickard, W. H., and B. E. Vaughan. 1988. Plant community characteristics and responses. In: W. H. Rickard, L. E. Rogers, B. E. Vaughan, and S. F. Liebetrau [EDS.]. Shrub-steppe: balance and change in a semi-arid terrestrial ecosystem. New York, NY, USA: Elsevier. p. 109-179.

RIDGWAY, R. 1877. United States geological exploration of the fortieth parallel. Part III. Ornithology. Washington, DC, USA: Government Printing Office. p. 303-669.

RHODE, D. 1999. The role of paleo-ecology in the development of Great Basin archeology, and vice-versa. In: C. Beck [ED.]. Models for the millennium: Great Basin archeology today. Salt Lake City, UT, USA: University of Utah Press. p. 29-49.

Riegel, G. M., R. F. Miller, C. D. Skinner, And S. E. Smith. 2006. Northeastern plateaus bioregion. In: N. G. Sugihara, J. W. van Wagtendonk, K. E. Shaffer, J. A. FitesKaufman, and A. E. Thode [EDS.]. Fire in California's ecosystems. Berkeley, CA, USA: University of California Press. p. 225-263.

Romme, W. H., C. D. Allen, J. D. Balley, W. L. Baker, B. T. Bestelmeyer, P. M. Brown, K. S. Eisenhart, M. L. Floyd, D. W. Huffman, B. F. Jacobs, R. F. Mlller, E. H. Muldavin, W. Swetnam, R. J. TAusch, AND P. J. WeisBerg. 2009. Historical and modern disturbance regimes, stand structures, and landscape dynamics in piñon-juniper vegetation of the western United States. Rangeland Ecology \& Management 62:203-222.

Roundy, B. A. 2005. Plant succession and approaches to community succession. In: N. L. Shaw, M. Pellant, and S. B. Monsen [comps.]. Sage-grouse Habitat Restoration Symposium Proceedings; 4-7 June 2001; Boise, ID, USA. Fort Collins, CO, USA: USDA Forest Service Rocky Mountain Research Station. Proceedings RMRS-P-38. p. 43-48.

Sands, A. R., S. Sather-Blair, and V. SaAb. 2000. Sagebrush steppe wildlife: historical and current perspectives. In: P. G. Entwistle, A. M. DeBolt, J. H. Kaltenecker, and K. Steenhof [comPs.]. Proceedings: Sagebrush Steppe Ecosystems Symposium; 21-23 June 1999; Boise, ID, USA. Boise, ID, USA: Bureau of Land Management. Publication No. BLM/ID/PT-001001+1150. p. 27-35.

Seefeldt, S. S., M. J. Germino, and K. DiCristina. 2007. Prescribed fires in Artemisia tridentata spp. vaseyana steppe have minor and transient effects on vegetation cover and composition. Applied Vegetation Science 10:249-256.

Sheley, R., J. James, B. Smith, and E. Vasquez. 2010. Applying ecologically based invasive-plant management. Rangeland Ecology \& Management 63:605-613.

Sheley, R. L., M. Manoukian, and G. Marks. 1999. Preventing noxious weed invasion. In: R. L. Sheley and J. K. Petroff [EDS.]. Biology and management of noxious rangeland weeds. Corvallis, OR, USA: Oregon State University Press. p. 69-72.

Shiflet, T. N. [Ed.]. 1994. Rangeland cover types of the United States. Denver, CO, USA: Society for Range Management. $152 \mathrm{p}$.

SHINN, D. A. 1980. Historical perspectives on range burning in the Inland Pacific Northwest. Journal of Range Management 33:415-423.

Stebleton, A., and S. Bunting. 2009. Guide for quantifying fuels in the sagebrush steppe and juniper woodlands of the Great Basin. Denver, C0, USA: Bureau of Land Management. Technical Note 430. $81 \mathrm{p}$.

Steward, J. H. 1933. Ethnography of the Owens Valley Paiute. University of California Publications in American Archaeology and Ethnology 33(5):423-438.

Steward, J. H. 1938. Basin-plateau aboriginal sociopolitical groups. Washington, DC, USA: Smithsonian Institution Bureau of American Ethnology. Bulletin 120. 346 p.

Steward, J. H. 1941. Culture element distributions: XIII, Nevada Shoshoni. University of California Anthropological Records 4:209-359. 
Steward, J. H. 1943. Culture element distributions: XXIII, Northern and Gosiute Shoshoni. University of California Anthropological Records 8:263-392.

SteWARD, J. H. 1949. Anthropology and renewable resources. In: Proceedings of the Inter-American Conference on Conservation of Renewable Natural Resources; $7-$ 20 September 1948; Denver, C0, USA. Washington, DC, USA: Department of State. p. 277-281.

StEWART, G. 1941. Historic record bearing on agriculture and grazing ecology in Utah. Journal of Forestry 39:362-375.

StewarT, 0. C. 1942. Culture element distributions: XVIII, Ute-Southern Paiute. University of California Anthropological Records 6:231-360.

SteWART, O. C. 1956. Fire as the first great force employed by man. In: W. L. Thomas, Jr. [ED.]. Man's role in changing the face of the earth. Chicago, IL, USA: University of Chicago Press. p. 115-133.

SteWART, 0. C. 1963. Barriers to understanding the influence of use of fire by aborigines on vegetation. In: E. V. Komarek [CoNF. CHAIR]. Proceedings, 2nd Tall Timbers Fire Ecology Conference; 14-15 March 1963. Tallahassee, FL, USA: Tall Timbers Research Station. p. 117-126.

SteWART, 0. C. 2002. Forgotten fires: Native Americans and the transient wilderness. Edited and with critique chapters by H. T. Lewis and M. K. Anderson. Norman, OK, USA: University of Oklahoma Press. $364 \mathrm{p}$.

Swetnam, T. W., C. D. Allen, and J. L Betancourt. 1999. Applied historical ecology: using the past to manage for the future. Ecological Applications 9:1189-1206.

ThomAs, D. H. 1983. The archaeology of Monitor Valley: 1. Epistemology. New York, NY, USA: American Museum of Natural History. Anthropological Papers of the American Museum of Natural History Volume 58: Part 1. 194 p.

Tisdale, E. W., AND M. HiRonaka. 1981. The sagebrush-grass region: a review of the ecological literature. Moscow, ID, USA: University of Idaho. Idaho Forest, Wildlife, and Range Experiment Station Bulletin 33. $31 \mathrm{p}$.

Touchan, R., C. D. Allen, and T. W. Swetnam. 1996. Fire history and climatic patterns in ponderosa pine and mixed conifer forests of the Jemez Mountains, northern New Mexico. In: C. D. Allen [TECH. ED.]. Fire Effects of Southwestern Forests: Proceedings of the Second La Mesa Fire Symposium; 29-31 March 1994; Los Alamos, NM, USA. Fort Collins, CO, USA: USDA Forest Service. General Technical Report RM-286. p. 33-46.

TURNER, N. J. 1991. Burning mountain sides for better crops: aboriginal landscape burning in British Columbia. Archeology in Montana 32:57-73.

URESK, D. W., J. F. CLINE, AND W. H. RICKARD. 1976. Impact of wildfire on three perennial grasses in south-central Washington. Journal of Range Management 29:309-310.

Uresk, D. W., W. H. Rickard, and J. F. Cline. 1980. Perennial grasses and their response to a wildfire in south-central Washington. Journal of Range Management 33:111-114.

[USDOE] US Department of Energy. 1979. Final environmental impact statement. Los Alamos Scientific Laboratory Site, Los Alamos, New Mexico. Springfield, VA, USA: National Technical Information Service. DOE/EIS-0018. 650 p.
US Forest Service. 2011. Fire Effects Information System Glossary. Available at: http://www.fs.fed.us/database/feis/glossary.html. Accessed 15 July 2011.

VALE, T. R. 1975. Presettlement vegetation in the sagebrush-grass area of the Intermountain West. Journal of Range Management 28:32-36.

VaLE, T. R. 2002. Reflections. In: T. R. Vale [ED.]. Fire, native peoples, and the natural landscape. Washington, DC, USA: Island Press. p. 295-301.

Verts, B. J., and Carraway, L. N. 1998. Land mammals of Oregon. Berkeley, CA, USA: University of California Press. 668 p.

Wigand, P. E., M. L. Hemphill, S. Sharpe, and S. Patra. 1995. Great Basin semi-arid woodland dynamics during the late Quaternary. In: W. J. Waugh [ED.]. Proceedings: climate change in the four corners and adjacent regions: implications for environmental restoration and land-use planning. Grand Junction, CO, USA: Mesa State College. US Department of Energy. p. 51-70.

Wiluıms, G. W. 2000. Introduction to aboriginal fire use in North America. Fire Management Today 60:8-12.

Wisdom, M. J., M. M. Rowland, B. C. Wales, M. A. Hemstrom, W. J. Hann, M. G. Raphael, R. S. Holthausen, R. A. Gravenmier, and T. D. Rich. 2002. Modeled effects of sagebrush-steppe restoration on greater sage-grouse in the Interior Columbia Basin, USA. Conservation Biology 16:1223-1231.

WriGHt, H. A. 1971. Why squirreltail is more tolerant to burning than needle-andthread. Journal of Range Management 24:277-284.

Wright, H. A., AND A. W. Balley. 1982. Fire ecology: United States and southern Canada. New York, NY, USA: John Wily and Sons. $501 \mathrm{p}$.

WriGht, H. A., AND J. O. KLemmedson. 1965. Effect of fire on bunchgrasses of the sagebrush-grass region in southern Idaho. Ecology 46:680-688.

Wrobleski, D. W., and J. B. Kauffman. 2003. Initial effects of prescribed fire on morphology, abundance, and phenology of forbs in big sagebrush communities in southeastern Oregon. Restoration Ecology 11:82-90.

YоAкUM, J. 1974. Pronghorn habitat requirements for sagebrush-grasslands. Proceedings of the Pronghorn Antelope Workshop 6:16-24.

YoAkum, J. 1978. Pronghorn. In: J. L. Schmidt and D. L. Gilbert [EDS.]. Big game of North America, ecology and management. Harrisburg, PA, USA: Stackpole Books. p. 103-121.

Young, J. A., R. E. ECKERT, JR., AND R. A. Evans. 1979. Historical perspectives regarding the sagebrush ecosystem. In: Proceedings: The sagebrush ecosystem: a symposium; April 1978; Logan, UT, USA. Logan, UT, USA: Utah State University College of Natural Resources. p. 1-13.

Young, J. A., And R. A. Evans. 1981. Demography and fire history of a western juniper stand. Journal of Range Management 34:501-506.

Young, R. P. 1987. Fire ecology and management of plant communities of Malheur National Wildlife Refuge, southeastern Oregon [PhD dissertation]. Corvallis, OR, USA: Oregon State University. 169 p.

Young, R. P., and R. F. Miller. 1985. Response of Sitanion hystrix (Nutt.) J.G. to prescribed burning. American Midland Naturalist 33:225-242. 